\title{
ADVERTISING VALUE AND ATTITUDE TO CATALOGS AND STORE FLYER ADS AMONG CROATIAN CONSUMERS - SEM APPROACH
}

\section{VRIJEDNOST OGLASA I STAV O KATALOZIMA I TRGOVAČKIM LETCIMA KOD HRVATSKIH POTROŠAČA - SEM PRISTUP}

\author{
Market-Tržište \\ Vol. 32, No. 2, 2020, pp. 129-146 \\ UDK 659.89:659.11(497.5) \\ DOl http://dx.doi.org/10.22598/mt/2020.32.2.129 \\ Original scientific paper
}

\section{Damir Dobrinić}

University of Zagreb, Faculty of organization and informatics, Pavlinska 2, 42000 Varaždin, CROATIA, e-mail: damir.dobrinic@foi.hr

\begin{abstract}
Purpose - This research study aims to determine the influence of the factors of informativeness, entertainment, irritation, and credibility on the perception of the value of advertisements and the attitude to advertising through catalogs and store flyers among Croatian consumers.
\end{abstract}

Design/methodology/approach - In the research, testing a theoretical model of value perception, 354 correct answers were collected via email, Facebook groups, and Internet forums. Hypotheses were tested using structural equation modeling.

Findings and implications - The results of this research show that the informativeness, entertainment, and credibility are important predictors of the value of catalogs and flyer advertising. Irritation is not. Furthermore, entertainment, credibility, and perception of the advertisement's value have a positive and significant impact on the attitude to advertising through catalogs and store flyers. In addition to the scientific contribution, the research study has its practical significance as a guide to future marketing activities aimed at increasing the effectiveness of this type of advertising.

\section{Sažetak}

Svrha - Cilj je istraživanja utvrditi kod hrvatskih potrošača utjecaj čimbenika informativnosti, zabave, iritacije i vjerodostojnosti oglasa na percepciju njegove vrijednosti i stav o oglašavanju putem kataloga i trgovačkih letaka.

Metodološki pristup - Istraživanje testira teorijski model percipirane vrijednosti. Putem elektroničke pošte, Facebook grupa i internetskih foruma prikupljeno je 354 valjanih odgovora. Metoda modeliranja strukturnih jednadžbi (SEM) korištena je za testiranje hipoteza.

Rezultati i implikacije - Rezultati istraživanja pokazuju da su informativnost, zabava i vjerodostojnost važni prediktori vrijednosti oglašavanja putem kataloga i letaka, dok iritacija to nije. Nadalje, zabava, vjerodostojnost i percepcija vrijednosti oglasa imaju pozitivan i značajan utjecaj na stav o oglašavanju putem kataloga i letaka. Osim znanstvenog doprinosa, istraživanje ima i svoj praktični značaj kao vodič za buduće marketinške aktivnosti na podizanju učinkovitosti ove vrste oglašavanja.

Ograničenja - Ograničenje istraživanja vezano je uz nereprezentativnost uzorka s obzirom da je autor koristio 
Limitation - The sample representativeness may be a limiting factor of this research because the author used available email addresses, Facebook groups, and Internet portals.

Originality - A review of the bibliography available found that the applied value perception model had not previously been tested in the context of catalogs and store flyers. It builds on the current knowledge about the effectiveness of individual advertising media.

Keywords - catalogs, store flyers, model, the value of advertisements, attitude to advertising raspoložive adrese elektroničke pošte te Facebook grupe i internetske portale.

Doprinos - Pregledom dostupne literature utvrđeno je kako primijenjeni model percipirane vrijednosti dosad nije testiran u kontekstu kataloga i trgovačkih letaka. Time se nadograđuju dosadašnje spoznaje o efikasnosti pojedinih medija oglašavanja.

Ključne riječi - katalozi, trgovački letci, model, percepcija vrijednosti oglasa, stav o oglašavanju 


\section{INTRODUCTION}

The modern age of direct marketing is believed to have begun with the emergence of initial promotional materials delivered to potential customers in numerous ways. The first such material in paper form appeared in Europe as early as 1498 (Miller, 1995). It was a list of books that a certain Aldus Manutius published and sold. It was said to be the first catalog, but from its description, we can conclude that it was a classic flyer. This paper focuses on catalogs and flyers as two types of advertising material. According to existing definitions, catalogs are lists of products available to customers for purchase (Groucutt, Leadley \& Forsyth, 2004). Multiple sheets of paper are tied together. Flyers, unlike catalogs, consist of a single sheet of paper and are usually issued weekly. Synonyms include names such as leaflets, weekly grocery advertisements, free sheets, shopper, or handbills (Gázquez-Abad \& Sánchez-Pérez, 2009).

Geller (2002) said that catalogs can be retail, specialized, and business (B2B) catalogs. Given the manner and place of sale, retail catalogs are used in so-called mail-order sales, store sales, and sales in both cases. The subject of this paper is retail catalogs (so-called traffic generators) issued, as a rule, by retailers on a weekly basis. Such catalogs, as well as store flyers, appear in printed form, in online editions, or may be displayed visually on television and in newspapers. In printed form, they are delivered as unaddressed mail to home addresses or inserted in newspapers and magazines. Usually, retailers also keep them at the entrance to their stores. Their large quantities often cause adverse reactions and are treated as unsolicited mail or junk mail.

Store flyers, as they are usually called according to (Latusi, Vergura \& Lugli, 2014), are one of the most important forms of advertising. Miranda and Konya (2007) described store flyers as one of the techniques of feature advertising with an essential task of attracting customers to the store. This is a simple and relatively cheap form of advertising that, according to Srinivasan and Bodapati (2006), is the most cost-effective for retailers. Kato and Hoshino (2019) point to the fact that, as traffic generators, flyers positively affect retailers' sales and profit margins. On the other hand, Swoboda, Elsner, Foscht and SchrammKlein (2010) highlight that they are very well received by customers as a promotional tool.

Retail catalogs and flyers are undoubtedly a useful promotional tool in their printed form and as online editions. Given that a significant part of the promotional budget is spent on them, customers must have a positive attitude to this type of communication. A positive attitude affects their acceptance and approval and, thus, their higher efficiency. Aydogan, Aysuna and Aktan (2016) claim that attitude is the last step toward behavior.

This paper will test Ducoffe's model of perception of the value of advertisements displayed through catalogs and store flyers, and different attitudes to advertising through these media (Ducoffe, 1995). Conceptually, the model examines the impact of four variables (informativeness, entertainment, irritation, and credibility) on the perception of the value of advertisements in these media and the relationship of value perception with the attitude to advertising through catalogs and store flyers. It is an approach that measures the effectiveness of advertising from the aspect of customers or participants in such promotional communication (Zhang \& Wang, 2005). Their perceptions of values and attitudes can serve to predict their behavior.

According to current knowledge, the effectiveness of advertising through retail catalogs and flyers, from the aspect of the perception of the value of advertisements and attitudes to advertising through these media, has not been the subject of scientific research so far. This paper aims to contribute to the development of knowledge in this area. A testing of Ducoffe's model will investigate: a) the impact of antecedents informativeness, entertainment, irritation, and credibility on the perception of the value of ads in catalogs and flyers; b) the impact of

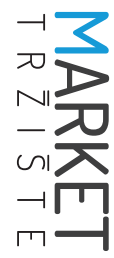




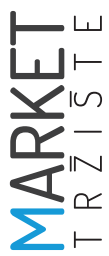

antecedents informativeness and credibility on the overall attitude to advertising through catalogs and store flyers; and c) the influence of the perception of advertisement value on the overall attitude to advertising.

The results of this research can also help advertisers who use catalogs and flyers to understand customers better. Understanding the element of influence on how their values and attitudes to advertising are formed allows for greater efficiency of future advertising and sales campaigns. The paper comprises five parts. An overview of previous research and findings on the subject follows the introductory section. The third part of the paper details the methodology of the study, while the fourth part presents data analysis and the results of this analysis. The concluding discussion, research limitations, and recommendations for further research form the final, fifth part the paper.

\section{LITERATURE OVERVIEW AND HYPOTHESES DEVELOPMENT}

According to Kotler and Amstrong (2018), the entire marketing concept is based on an exchange process. Bagozzi (1975) defines exchange as a "transfer of something tangible or intangible, actual or symbolic, between two or more actors." Ducoffe and Curlo (2000) believe that advertising messages can also be viewed in the context of the exchange of values between the advertiser and the customer. According to Houston and Gassenheimer (1987), each party in the exchange gives and receives some value, with an advertising message the advertiser wants to achieve being a specific goal. In order to achieve it, the ad should meet (or exceed) certain customer expectations or expected value. Knopper (1993) describes ad value as one of the essential determinants of customer response, while Ducoffe (1996) defines ad value as a "subjective evaluation of the relative worth or utility of advertising to the consumer." In other words, the value of the ad can be considered an index of customer satisfaction with promotional communication; the higher it is, the more positive the reactions. Numerous studies confirm the direct association of customers' attitudes to advertising with their efficacy (Mehta, 2000), as well as with customer behavior (Boateng \& Okoe, 2015; Awan, Ismail, Majeed \& Gmazal, 2016; Subroto \& Samidi, 2018).

Customer expectations or expected ad value can also be measured through the dimensions defined by Ducoffe (1996) in his Advertising Value Model. These are informativeness, entertainment, irritation, and credibility. The analysis of these dimensions determines positive and negative influences on the formation of the ad value. They are managed for the purpose of satisfying the needs of customers, that is, achieving the goal of their getting what they want. Managing ad value factors influences advertising attitudes.

This paper examines the advertising value and the attitude of customers to advertising that is carried out through catalogs and store flyers. The advertising value and attitude tests are conducted based on the advertising value determination model developed by Ducoffe (1996) and upgraded by Braket and Carr (2001). This model examines the influence of individual factors on the experience and perception of the value of advertising and the attitude to advertising. According to Zhang and Wang (2005), there is a difference between ad value and advertising attitudes. The consumer may not like the ad itself but may find advertising as a whole to be valuable and useful. In addition to the impact of ad value, the impact of entertainment and credibility on advertising attitudes is also examined. The advertising value model has often been used in research into the effectiveness of advertising in various media. According to Murillo, Merino and Núñez (2016), it is also considered the most effective model in understanding and determining attitudes to advertising and predicting customer behavior. Based on the above, the following conceptual research model was developed (Figure 1). 
FIGURE 1: Conceptual model of research

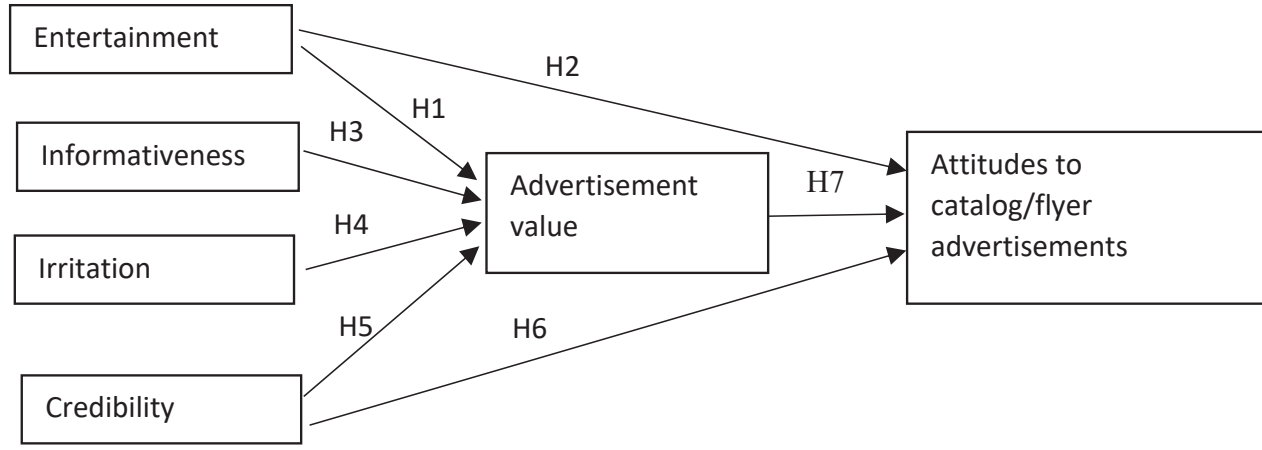

Source: The author

\subsection{Entertainment}

Ducoffe (1995) defined entertainment in the context of advertising (based on Uses and Gratification Theory - UGH) as "the ability of advertising to fulfill consumer needs for escapism, diversion, aesthetic enjoyment or emotional release". Wang, Genc and Peng (2019) extended this to "interesting, pleasurable, and emotional experiences." By testing the advertising value model in different contexts/media, researchers have found a significant association between and the impact of entertainment on the perception of ad value. Table 1 shows a list of relevant research related to different advertising media.

TABLE 1: Positive impact of entertainment on the perception of ad value

\begin{tabular}{|l|l|}
\hline $\begin{array}{l}\text { Ducoffe (1995); Bracket \& Carr } \\
\text { (2001); Aydogan et al. (2016) }\end{array}$ & Web ads \\
\hline Murilo et al. (2016) & Twitter ads \\
\hline $\begin{array}{l}\text { Tsang, Ho \& Liang (2004); Kim \& } \\
\text { Han (2014) }\end{array}$ & Mobile ads \\
\hline $\begin{array}{l}\text { Rejesh, Raj, Dhuvandranand \& } \\
\text { Kiran (2019); Noprisson et al. (2016) }\end{array}$ & $\begin{array}{l}\text { SMS (text) } \\
\text { ads }\end{array}$ \\
\hline $\begin{array}{l}\text { Arora \& Agarwal (2019); Noprisson } \\
\text { et al. (2016) }\end{array}$ & $\begin{array}{l}\text { Social } \\
\text { media ads }\end{array}$ \\
\hline $\begin{array}{l}\text { Hamouda (2018); Dar, Ahmed, } \\
\text { Mazuffar, Nawaz \& Zahid (2014) }\end{array}$ & $\begin{array}{l}\text { Facebook } \\
\text { ads }\end{array}$ \\
\hline Dar et al. (2014) & TV ads \\
\hline Haq (2009); Noprisson et al. (2016) & Email ads \\
\hline
\end{tabular}

Source: The author
The model also investigates the impact of ad entertainment on advertising attitudes. In previous research, the authors have proved the existence of a direct positive connection between and the impact of entertainment on the formation of attitudes to advertising (Ducoffe, 1995; Bracket \& Carr, 2001; Bennet, Ferraira, Tsuji \& Cionfrone, 2006; Huq, Alam, Nekmahmud, Aktar \& Alam, 2015; Murillo et al., 2016; Qin \& Yan, 2017; Yang, Huang, Yang \& Yang, 2017; Wang \& Lan, 2018). Hypotheses $H 1$ and $H 2$ were formed based on previous research and their findings:

$\mathrm{H1}$ : There is a significant positive impact of the entertainment factor of an advertisement on the advertising value of catalogs and store flyer ads.

$\mathrm{H} 2$ : There is a significant positive impact of the entertainment factor of an advertisement on consumers' attitudes to catalogs and store flyer advertising.

\subsection{Informativeness}

Raising product awareness and motivating people to buy is primarily related to information. The well-known AIDA promotional model defines this in the context of desire and actions (Kotler, Kartajaya \& Setiawan, 2017). In this regard, Inanç, Gökaliler and Gülay (2020) note how available or obtained information can guide or determine further customer behavior.

Catalogs and flyers have the role of informing customers about the offer, with an emphasis 
on prices (Kato \& Hoshino, 2019). Along these lines, Burton, Lichtenstein and Netemeyer (1999) described store flyers as a unique form of informative advertising. The importance of the informative role of flyers is also pointed out by Gázquez-Abad and Sánchez-Pérez (2009), who established a link between brand presentation and its selection. On the other hand, with their research Miranda and Kónya (2007) indicated a positive reaction of customers to additional information found on flyers. This information further explains the discount offers and prices and is useful in making the final purchase decision.

The informative role of advertising as a cognitive variable (Ducoffe, 1995) has an impact on the perception of ad value. Several papers confirmed and pointed to a significant positive correlation between the informative role of advertising and the formation of advertising value (Aaker \& Stayman, 1990; Ducoffe, 1996; Tsang et al., 2004; Haq, 2009; Dar et al., 2014; Aydogan et al., 2016; Rejesh et al., 2019). The review and analysis of the literature was the basis for hypothesis $\mathrm{H} 3$ :

H3: There is a significant positive impact of an advertisement's informativeness on the advertising value of catalogs and store flyer ads.

\subsection{Irritation}

In measuring the effectiveness of advertisement and advertising, Ducoffe (1995) points to irritability as an important variable influencing the value of advertising. If the recipient of the message perceives the message to be irritating, it will inevitably affect their perception of the value of the ad and attitude to such advertising. According to Ducoffe (1995), irritation is caused by advertisements perceived to be disturbing, offensive, insulting, and manipulative. Advertisers need to find out what is irritating. Various triggers such as generally poor approach and advertising tactics (Ducoffe, 1995) or too many ads in a short time, or a lot of repetition (Loureiro, 2017) can irritate, leading to ad avoidance. Ad avoidance, according to Spack and Elliot (1997), can be on a cognitive, behavioral, and mechanical level. Catalogs and flyers delivered to the home address at the mechanical level can be avoided by placing a "No-Junk Mail" sticker on a home mailbox (Simon, 2016). At the cognitive level, they are simply ignored by not taking or instantly discarding them (Spack \& Elliot, 1997). Those delivered by e-mail can be mechanically avoided by instantly deleting, unsubscribing from the list, or installing programs that disable them (Kelly, Kerr \& Drennan, 2010; Loureiro, 2017). This indicates that the perception of an ad as being irritating reduces its effectiveness and ability to capture immediate attention. In this sense, Kim and Lee (2009) examined the closedness of customers to the stimuli that the ads direct. Stewart and Pavlou (2002) noted that the perception of the irritability of advertisements or the media in which they are published causes their avoidance and the creation of a negative attitude to advertising. In their work on this topic, the authors find a negative correlation between irritation and perception of the value of advertising and irritation and attitude toward advertising (Ducoffe, 1995; Braket \& Carr, 2001; Tsang et al., 2004; Huq et al., 2015; Noprisson et al., 2016; Gaber, Wright \& Kooli, 2019; Inanç et al., 2020). Hypothesis H4 is formed according to previous research:

$\mathrm{H} 4$ : There is a significant negative impact of advertising irritation on the advertising value of catalogs and store flyer advertising.

\subsection{Credibility}

Bracket and Carr (2001) complemented the original Ducoffe model with antecedent credibility. In their paper, they found that the credibility of an ad has a significant positive impact on the perception of its value but also on the attitude to advertising. That the perception of the advertisement's credibility directly leads to positive attitudes about advertising is also confirmed by Azeem and Haq (2012). Stewart and Pavlou (2002) defined ad credibility as "consumers' perception of the truthfulness and believability of advertising in general." The opinion of Haller (1974), who believes that advertisements should be useful and believable, stands out for the purpose this paper. The role of catalogs and store flyers as promotional tools is to motivate customers to come 
to the store. The strongest motive for customers to come is a favorable offer or price (Garcia-Boto \& Alvarez, 2020; Mulhern \& Leone, 1990). Favorable price is a direct benefit perceived by customers; however, Grewal, Monroe, and Krishnan (1998) also emphasized transactional value as an important psychological benefit. Customers feel comfortable when paying less than the usual price. Gázquez-Abad, Martínez-López and Barrales-Molina (2014), analyzing behavior and preferences for store flyers, found that the perception of savings based on buying at a discounted price is essential to the credibility of the flyers.

By testing the Ducoffe model, previous papers have also explored the impact of ad credibility on the perception of ad value and attitudes to advertising. Their results show that there is a positive impact of credibility on the perception of value and attitude to advertising (Braket \& Carr, 2001; Huq et al., 2015; Murillo et al., 2016; Lin \& Bautista, 2018; Inanç et al., 2020). The findings of previous research are the basis of hypotheses $\mathrm{H} 5$ and $\mathrm{H} 6$ :

H5: There is a significant positive impact of ad credibility on the advertising value on catalogs and store flyers.

H6: There is a significant positive impact of ad credibility on the attitude to advertising through catalogs and store flyers.

\subsection{Perceived advertising value and attitude to the advertising}

Ducoffe (1995) defined advertising value as a "subjective evaluation of the relative value or utility of advertising to the consumer." The model examines the impact of antecedents - informativeness, entertainment, irritation, and credibility - on the perception of ad value and the impact of ad value on advertising attitudes. The prediction of customer behavior assumes that ads that are informative, entertaining, credible, and not very intrusive will positively affect the attitude to advertising, the brand, and the company as a whole (Tahereh \& Zahra, 2012). According to Dalrymple and Parsons (1995), attitude "is a mental state of readiness, organized through experience, exerting a directive influence on the individual's response to objects and situations with which it is related." Wood (2000) explains that an attitude to an object can range from distinctly positive to distinctly negative. Peppers and Rogers (2017), in turn, emphasize the importance of perspective on customer behavior. A customer who is satisfied and has a positive attitude to the company's products and services is more likely to become a loyal customer.

Previous research has established the existence of a positive correlation between perceived ad value and advertising attitudes (Ducoffe, 1995; Brackett \& Carr, 2001; Zhang \& Wang, 2005; Liu, Sinkovics, Pezderka \& Haghirian, 2012; Murillo et al., 2016; Aydogan et al., 2016; Arora \& Agarwal, 2019; Inanç et al., 2020). Hypothesis H7 was formed based on previous research:

H7: The advertising value of catalogs and store flyers has a significant positive impact on customers' attitudes to this type of advertising.

\section{RESEARCH METHODOLOGY}

\subsection{Scale development}

This research study explores the influence of certain factors in the Ducoffe model on the perception of ad value and attitude to advertising. The model measures the effectiveness of catalog and flyer advertising and, as such, can serve to predict customer behavior in terms of their future purchasing decisions. Regarding the purpose of the model, the research examines (a) the impact of entertainment, information, credibility, and irritability of ads on the perception of their value, (b) the impact of entertainment and credibility on the attitude of advertising through catalogs and flyers, and (c) the relationship and impact of perceived ad value on the attitude to advertising through catalogs and flyers. A 5-point Likert scale ranging from 1 = strongly disagree to $5=$ strongly agree was used to measure the variables in the model. Tables 2 and 3 show the measuring scale and sources. After the analysis, the range was corrected to make the model more representative.

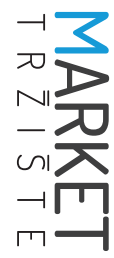


TABLE 2: Sources - measuring scales

\begin{tabular}{|l|l|c|c|}
\hline \multicolumn{1}{|c|}{ Construct } & \multicolumn{1}{|c|}{ Source } & $\begin{array}{r}\text { The initial } \\
\text { number of items }\end{array}$ & $\begin{array}{c}\text { The final number } \\
\text { of items }\end{array}$ \\
\hline Informativeness & Ducoffe (1996) & 6 & 4 \\
\hline Entertainment & Ducoffe (1995) & 5 & 4 \\
\hline Irritation & Ducoffe (1995); Bracket \& Car (2003) & 5 & 3 \\
\hline Credibility & $\begin{array}{l}\text { Bracket \& Car (2003); Yang, Kim \& } \\
\text { Yoo (2013); Murillo et al. (2016) }\end{array}$ & 5 & 3 \\
\hline Advertising value & Ducoffe (1995); Bracket \& Car (2003) & 3 & 4 \\
\hline $\begin{array}{l}\text { Attitudes toward } \\
\text { advertising }\end{array}$ & $\begin{array}{l}\text { Pollay \& Mittal (1993); Milaković \& } \\
\text { Mihić (2015) }\end{array}$ & 4 & \multicolumn{2}{|c|}{} \\
\hline
\end{tabular}

Source: The author

TABLE 3: Original measurement items

\begin{tabular}{|c|c|c|}
\hline Construct & & Measurement items \\
\hline Informativeness & $\begin{array}{l}\mathbb{I N 1} 1^{*} \\
\mathbb{N} 2 \\
\text { IN3 } \\
\text { IN4 } \\
\text { IN5 } \\
\text { IN6* }\end{array}$ & $\begin{array}{l}\text { Catalogs and flyers are reliable sources of product/service information. } \\
\text { Catalogs and flyers supply relevant product information. } \\
\text { Catalogs and flyers provide timely information. } \\
\text { Catalogs and flyers are reliable sources of up-to-date product/service information. } \\
\text { Catalogs and flyers are convenient sources of product/service information. } \\
\text { Catalogs and flyers make product/service information immediately accessible. }\end{array}$ \\
\hline Entertainment & $\begin{array}{l}\text { EN1 } \\
\text { EN2 } \\
\text { EN3* } \\
\text { EN4 } \\
\text { EN5 }\end{array}$ & $\begin{array}{l}\text { Catalogs and flyers are entertaining. } \\
\text { Catalogs and flyers are pleasing. } \\
\text { Catalogs and flyers are exciting. } \\
\text { Catalogs and flyers are enjoyable. } \\
\text { Catalogs and flyers are fun to use. }\end{array}$ \\
\hline Irritation & $\begin{array}{l}\mathbb{R} 1 \\
\mathbb{R} 2 \\
\mathbb{R} 3^{*} \\
\mathbb{R} 4^{*} \\
\mathbb{R} 5^{* *}\end{array}$ & $\begin{array}{l}\text { Catalogs and flyers are annoying. } \\
\text { Catalogs and flyers are irritating. } \\
\text { Catalogs and flyers are deceptive. } \\
\text { Catalogs and flyers are confusing. } \\
\text { Catalogs and flyers insult people's intelligence. }\end{array}$ \\
\hline Credibility & $\begin{array}{l}\text { CR1* } \\
\text { CR2 } \\
\text { CR3 } \\
\text { CR4 } \\
\text { CR5* }\end{array}$ & $\begin{array}{l}\text { Catalogs and flyers are convincing. } \\
\text { Catalogs and flyers are credible. } \\
\text { Catalogs and flyers are trustworthy. } \\
\text { Catalogs and flyers are believable. } \\
\text { I believe that catalogs and flyers ads are a useful reference for purchasing products. }\end{array}$ \\
\hline Advertising value & $\begin{array}{l}\text { VA1 } \\
\text { VA2 } \\
\text { VA3 }\end{array}$ & $\begin{array}{l}\text { Catalogs and flyers are useful. } \\
\text { Catalogs and flyers are valuable. } \\
\text { Catalogs and flyers are important. }\end{array}$ \\
\hline $\begin{array}{l}\text { Attitudes to } \\
\text { advertisement }\end{array}$ & $\begin{array}{l}\text { ATT1 } \\
\text { ATT2 } \\
\text { ATT3 } \\
\text { ATT4 }\end{array}$ & $\begin{array}{l}\text { Overall, I consider catalogs and flyers a good thing. } \\
\text { Overall, I like catalogs and flyers. } \\
\text { My general opinion about catalogs and flyers is favorable. } \\
\text { I like to look at catalogs and flyers. }\end{array}$ \\
\hline
\end{tabular}




\subsection{Data collection and participants}

An online survey, created in Google Docs and made publicly available, was conducted for the purpose of research. The survey was carried out during March and April 2020. A link to the survey was forwarded to 2500 e-mail addresses via MailChimp service and posted on several Facebook groups and online forums. Three hundred and fifty-four (354) duly completed questionnaires were collected. The adequacy of the number of participants in the study also determines the number of observed factors (variables), and researchers say that this number can range from two to 20 respondents per variable. As the tested model examines the interrelationship between six factors (variables), it means that the number of participants in the research can be considered satisfactory. The participants' demographic structure is as follows: 113 men (31.9\%) and 241 women (68.1\%). Table 4 shows their age.

TABLE 4: Gender - age

\begin{tabular}{|l|c|c|c|}
\hline Age & Age & Frequency & $\mathbf{\%}$ \\
\hline Generation Z & $18-25$ & 77 & 21.8 \\
\hline Millennials & $26-40$ & 121 & 34.2 \\
\hline Generation X & $41-54$ & 107 & 30.2 \\
\hline Boomers & $>54$ & 49 & 13.8 \\
\hline
\end{tabular}

Source: The author

As part of general questions, participants were asked how they view catalogs and store flyers (in print or online) and the reasons for using catalogs and store flyers. The results are shown in Tables 5 and 6.

TABLE 5: Answer to the question "How I view catalogs and flyers"

\begin{tabular}{|l|c|}
\hline Online & $16.1 \%$ \\
\hline Printed form & $18.6 \%$ \\
\hline Both (print form and online) & $58.2 \%$ \\
\hline I do not look [at them] & $7.1 \%$ \\
\hline
\end{tabular}

Source: The author
TABLE 6: Answer to the question "Reason for using catalogs and flyers"

\begin{tabular}{|l|c|}
\hline $\begin{array}{l}\text { Savings - price comparison } \\
\text { between stores }\end{array}$ & $34.2 \%$ \\
\hline $\begin{array}{l}\text { Searching for new products, ideas, } \\
\text { and useful information }\end{array}$ & $42.4 \%$ \\
\hline $\begin{array}{l}\text { Faster and easier purchase (list } \\
\text { creation and purchase from your } \\
\text { nearest store) }\end{array}$ & $14.1 \%$ \\
\hline $\begin{array}{l}\text { Detailed product comparisons } \\
\text { and highest value searches for me }\end{array}$ & $9.3 \%$ \\
\hline
\end{tabular}

Source: The author

\section{DATA ANALYSIS}

As part of the analysis of the collected data, the reliability of the measuring construct was first assessed by performing exploratory factor analysis (EFA). The SPSS 23 software package was used to implement the EFA. Confirmatory factor analysis (CFA) was used to test the hypotheses about the structure and relationship between latent variables. CFA was performed using the SPSS AMOS 26 software package. The maximum likelihood method (ML) was used.

\subsection{Internal reliability of the construct}

The internal consistency and reliability of the construct were measured by determining Cronbach's alpha, alpha-if-deleted, and item-total-correlation. Cronbach's alpha values for each of the six sub-scales ranged from 0.885 to 0.933 . According to Field (2013), any values above 0.7 are acceptable. Table 7 shows the internal consistency and reliability of the construct.

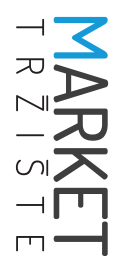


TABLE 7: Internal reliability and convergent validity

\begin{tabular}{|c|c|c|c|c|c|c|c|c|}
\hline & & Internal & reliability & & Convergent & validity & & \\
\hline Construct & Item & $\begin{array}{c}\text { Cronbach's } \\
\text { alpha }\end{array}$ & $\begin{array}{l}\text { Item-total } \\
\text { correlation }\end{array}$ & $\begin{array}{c}\text { Factor } \\
\text { loading }\end{array}$ & $\begin{array}{l}\text { Composite } \\
\text { reliability }\end{array}$ & AVE & Mean & SD \\
\hline Informativeness & $\begin{array}{l}\text { IN1 } \\
\text { IN2 } \\
\text { IN3 } \\
\text { IN4 }\end{array}$ & .871 & $\begin{array}{l}.717 \\
.711 \\
.717 \\
.753 \\
\end{array}$ & $\begin{array}{l}.805 \\
.781 \\
.772 \\
.813 \\
\end{array}$ & .871 & .628 & $\begin{array}{l}3.51 \\
3.94 \\
3.83 \\
3.82 \\
\end{array}$ & $\begin{array}{l}0.925 \\
0.912 \\
0.961 \\
0.934 \\
\end{array}$ \\
\hline Entertainment & \begin{tabular}{|l} 
EN1 \\
EN2 \\
EN3 \\
EN4 \\
\end{tabular} & .924 & $\begin{array}{l}.858 \\
.787 \\
.839 \\
.816 \\
\end{array}$ & $\begin{array}{l}.888 \\
.830 \\
.894 \\
.862\end{array}$ & .924 & .754 & $\begin{array}{l}3.09 \\
3.25 \\
3.29 \\
2.93\end{array}$ & $\begin{array}{l}1.155 \\
1.070 \\
1.071 \\
1.221 \\
\end{array}$ \\
\hline Irritation & $\begin{array}{l}\text { IR1 } \\
\text { IR2 } \\
\text { IR3 }\end{array}$ & .769 & $\begin{array}{l}.682 \\
.733 \\
.419\end{array}$ & $\begin{array}{l}.888 \\
.864 \\
.461\end{array}$ & .796 & .582 & $\begin{array}{l}2.58 \\
2.36 \\
1.72\end{array}$ & $\begin{array}{l}1.153 \\
1.103 \\
1.032\end{array}$ \\
\hline Credibility & $\begin{array}{l}\text { CR1 } \\
\text { CR2 } \\
\text { CR3 }\end{array}$ & .929 & $\begin{array}{l}.844 \\
.887 \\
.834\end{array}$ & $\begin{array}{l}.896 \\
.943 \\
.870\end{array}$ & .930 & .816 & $\begin{array}{l}3.42 \\
3.43 \\
3.54\end{array}$ & $\begin{array}{l}0.848 \\
0.872 \\
0.841\end{array}$ \\
\hline $\begin{array}{l}\text { Advertising } \\
\text { value }\end{array}$ & $\begin{array}{l}\text { VA1 } \\
\text { VA2 } \\
\text { VA3 } \\
\end{array}$ & .885 & $\begin{array}{l}.675 \\
.842 \\
.829\end{array}$ & $\begin{array}{l}1.011 \\
.926 \\
.923\end{array}$ & .968 & .910 & $\begin{array}{l}3.95 \\
3.24 \\
3.25\end{array}$ & $\begin{array}{l}0.883 \\
0.993 \\
1.032 \\
\end{array}$ \\
\hline $\begin{array}{l}\text { Attitudes to } \\
\text { advertisement }\end{array}$ & $\begin{array}{l}\text { ATT1 } \\
\text { ATT2 } \\
\text { ATT3 } \\
\text { ATT4 }\end{array}$ & .933 & $\begin{array}{l}.849 \\
.900 \\
.851 \\
.800\end{array}$ & $\begin{array}{l}.891 \\
.941 \\
.892 \\
.836\end{array}$ & .938 & .793 & $\begin{array}{l}3.89 \\
3.61 \\
3.84 \\
3.61\end{array}$ & $\begin{array}{l}0.954 \\
1.048 \\
0.942 \\
1.195\end{array}$ \\
\hline
\end{tabular}

Source: The author

\subsection{Confirmatory factor analysis (CFA)}

CFA using the AMOS 26 structural equation modeling software was performed to determine the level of agreement between the theoretical model and empirical data. Validity is tested to determine whether a measuring instrument measures what it should measure (Ahmad, Zulkurnain \& Khairushalimi, 2016). Convergent validity is shown by calculating the composite reliability coefficient (CR) and the average variance extracted (AVE). An acceptable value for CR is that above 0.6 and for AVE above 0.5 (Ahmad et al., 2016). The values obtained that are shown in Table 7 confirm the convergent validity of measurement scales. The discriminant validity of the measurement scale was tested to check the correlation of variables in various factors. The result in Table 8 shows that the variables do not correlate strongly with other variables in other factors. The square root of AVE is higher than the correlation among factors. The correlation between the factors is less than 0.85, which, according to Tüzünkan and Altintas (2019), is a good indicator of the discriminant validity of the construct. 
TABLE 8: Discriminant Validity

\begin{tabular}{|l|c|c|c|c|c|c|}
\hline & $\begin{array}{c}\text { Informa- } \\
\text { tiveness }\end{array}$ & Entertainment & Irritation & Credibility & $\begin{array}{c}\text { Advertising } \\
\text { value }\end{array}$ & Attitude \\
\hline Informativeness & $\mathbf{0 . 7 9 2}$ & & & & & \\
\hline Entertainment & 0.517 & $\mathbf{0 . 8 6 8}$ & & & & \\
\hline Irritation & -0.466 & -0.688 & $\mathbf{0 . 7 6 2}$ & & & \\
\hline Credibility & 0.675 & 0.469 & -0.326 & $\mathbf{0 . 9 0 3}$ & & \\
\hline $\begin{array}{l}\text { Advertising } \\
\text { value }\end{array}$ & 0.622 & 0.601 & -0.480 & 0.616 & $\mathbf{0 . 9 5 3}$ & \\
\hline $\begin{array}{l}\text { Attitude to } \\
\text { advertising }\end{array}$ & 0.628 & 0.759 & -0.663 & 0.619 & 0.807 & $\mathbf{0 . 8 9 0}$ \\
\hline
\end{tabular}

Source: The author

\subsection{Structural Equation Modeling (SEM)}

Structural equation modeling (SEM) analysis was performed to determine how successfully the model describes the correlation between independent and dependent variables (determining the suitability of the model). It was performed with the help of the SPSS AMOS statistical software package. As part of the SEM analysis, the relationships between antecedents defined by the conceptual model were tested by measuring the goodness of fit: GFI, AGFI, IFI, TLI, NFI, CFI, RMSEA, and SRMR. The tested theoretical model did not show satisfactory values (RMSA $>0.008, \mathrm{GFI}<0.8, \mathrm{AGFI}<0.8, \mathrm{IFI}>0.9$, TLi $<0.9, \mathrm{NFI}<0.9, \mathrm{CFI}<0.9$ and SRMR $>0.08$ ) (Table 8). By correcting the measurement scale, the following questions (items) were removed: IN1, IN6, EN3, IRI3, IR4, CR1, and CR5 (Table 2). The values measured in the modified structural model are shown in Table 9. The modified structural model for catalog and store flyer advertising is available in Figure 2.

TABLE 9: Fit indices

\begin{tabular}{|l|c|c|c|l|}
\hline \multicolumn{1}{|c|}{ Fit index } & Test model & $\begin{array}{c}\text { Modification } \\
\text { model }\end{array}$ & $\begin{array}{c}\text { Recommended } \\
\text { value }\end{array}$ & \multicolumn{1}{|c|}{ Source } \\
\hline Chi-square & $\begin{array}{c}1289,4 ; \mathrm{df}=337, \\
\mathrm{p}<0,001\end{array}$ & $\begin{array}{c}487,014 ; 174 \\
\mathrm{p}<.0,001\end{array}$ & & \\
\hline $\mathrm{X}^{2} / \mathrm{df}$ & 3.82 & 2.799 & $<5$ & Park \& Kim (2014) \\
\hline $\mathrm{GFI}$ & 0.765 & 0.875 & $>0.8$ & Halmi (2016) \\
\hline $\mathrm{AGFI}$ & 0.717 & 0.834 & $>0.8$ & Halmi (2016) \\
\hline $\mathrm{IFI}$ & 0.885 & 0.952 & $>0.9$ & Park \& Kim (2014) \\
\hline TLI & 0.871 & 0.942 & $>0.9$ & Kim \& Han (2014) \\
$\mathrm{NFI}$ & 0.851 & 0.928 & $>0.9$ & Park \& Kim (2014) \\
\hline CFI & 0.885 & 0.952 & $>0.9$ & Hu \& Bentler (1999) \\
\hline RMSEA & 0.089 & 0.071 & $0.03-0.08$ & Hair, Black, Babin \& \\
\hline SRMR & 0.089 & 0.067 & $<0.08$ & Hair et al. (2014) \\
\hline
\end{tabular}

Source: The author 
FIGURE 2: Structural model for catalogs and flyer advertising

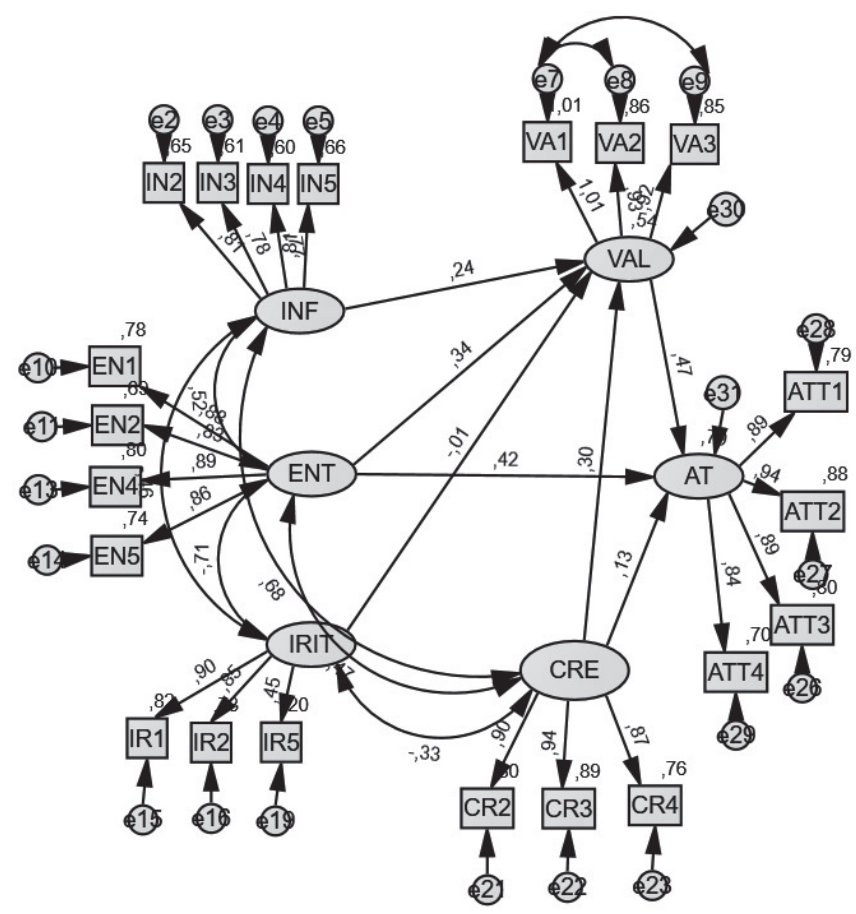

\subsection{Hypothesis tests}

Table 10 and Figure 3 show the results of hypothesis testing.

Table 10: Summary of hypothesis testing results

\begin{tabular}{|l|c|c|c|c|c|c|}
\hline Hypothesis & $\begin{array}{c}\text { Independent } \\
\text { variable }\end{array}$ & $\begin{array}{c}\text { Dependent } \\
\text { variable }\end{array}$ & $\begin{array}{c}\text { Standard } \\
\text { estimate }\end{array}$ & CR & P-value & Supported \\
\hline$H 1(+)$ & ENT & VAL & 0.338 & 6.112 & $* * *$ & Supported \\
\hline$H 2(+)$ & ENT & ATT & 0.422 & 10.120 & $* * *$ & Supported \\
\hline$H 3(+)$ & INF & VAL & 0.235 & 4.441 & $* * *$ & Supported \\
\hline H4 (-) & IRIT & VAL & -0.010 & -0.198 & 0.843 & N/S \\
\hline$H 5(+)$ & CRE & VAL & 0.297 & 5.994 & $* * *$ & Supported \\
\hline H6 (+) & CRE & ATT & 0.130 & 3.348 & $* * *$ & Supported \\
\hline$H 7(+)$ & VAL & ATT & 0.472 & 8.517 & $* * *$ & Supported \\
\hline
\end{tabular}

*** $P<0,001$

CR - Critical value, INF - Informativeness, ENT - Entertainment, IRIT - Irritation, CRE - Credibility, VAL - catalog and flyer advertising value, ATT - Attitude to catalog and flyer advertising, N/S - Not supported 
FIGURE 3: Results of hypothesis testing

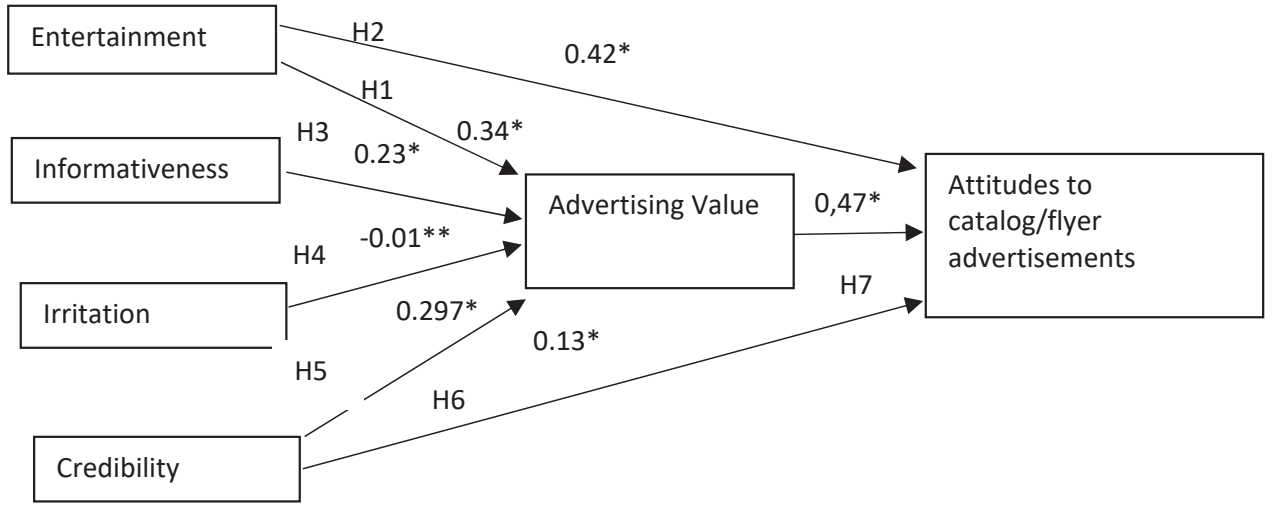

Note: ${ }^{* * P}>0.05 ;{ }^{*} P<0.001$

The representativeness of the model was measured by calculating the coefficient of determination (R2). The coefficient "is a measure of the amount of variability in one variable that is shared by the other." Table 11 shows the measured values. The values show that $53.9 \%$ of the variance in value perception was explained by the influence of independent variables (entertainment, informativeness, irritation, and credibility). As shown in Figure 3, the influence of entertainment and credibility on the perception of value is dominant.

On the other hand, independent variables (entertainment, credibility, and catalog/flyer advertising value) explain $78.6 \%$ of the variance of the dependent variable (consumer attitude to catalog and flyer advertising). Credibility was found to have the least impact on the attitude to advertising. (Figure 3 ) The results show good representativeness of the model.

TABLE 11: Squared multiple correlations of the proposed research model

\begin{tabular}{|c|c|}
\hline Construct & $\begin{array}{c}\text { Values } \\
\%\end{array}$ \\
\hline Catalog/flyer advertising value & $\begin{array}{c}53.9 \\
(0.539)\end{array}$ \\
\hline $\begin{array}{l}\text { Attitude to the catalog/flyer } \\
\text { advertisement }\end{array}$ & $\begin{array}{c}78.6 \\
(0.786)\end{array}$ \\
\hline
\end{tabular}

Source: author

\section{DISCUSSION AND IMPLICATIONS}

A review of previous theoretical knowledge about advertising through catalogs and flyers has shown a lack of scientific papers on the perception of value and customer attitudes to this type of advertising. In this regard, research on this topic was planned, and goals were set. This paper aims to investigate the factors influencing customers' attitudes to advertising through catalogs and store flyers and determine the strength of that influence and the interrelationship between the elements. The research was carried out on empirical data collected through a survey in the Republic of Croatia. The research tested Ducoffe's ad value model based on UGH theory. By exploring the factors influencing the perception of the value of advertising and attitudes to advertising, the model examines the effectiveness of ads and advertising and directs future activities towards their improvement.

Based on the theoretical model, a conceptual research framework was developed to examine the impact of four variables (entertainment, informativeness, irritation, and credibility) on the perception of ad value. In addition to the perception of value, the attitude to advertising, which is influenced by three independent variables (entertainment, credibility, and advertising value), was also examined. Accordingly, 
hypotheses were formed and tested. Hypotheses $\mathrm{H} 1$ and $\mathrm{H} 2$ were confirmed: entertainment factor has a significant impact on advertising value and advertisement attitudes. Respondents' opinion regarding the entertainment of ads in catalogs and flyers was found to be mostly neutral (mean range of 2.93-3.29 on a 5-point scale). Hypothesis H3 was also confirmed: advertisement's informativeness has a significant impact on advertising value. Respondents believe the informative role of advertisements in catalogs and flyers to be important (mean range of 3.51-3.94). Hypothesis H4, "There is a significant negative impact of advertising irritation on advertising value of catalogs and store flyer advertising.", was rejected. Testing of the empirical data found that irritation has no significant negative impact on the perception of ad value, which is inconsistent with previous research in the context of other media. Respondents in this research outlined savings (34.2\%) and searching for new products, ideas, and useful information (42.4\%) as the main reasons for using catalogs and flyers. The assumption is that this direct benefit suppresses the influence of irritating elements. Hypotheses $\mathrm{H} 5$ and $\mathrm{H} 6$ were confirmed: the credibility factor has a significant impact on advertising value and advertisement attitudes. Respondents see credibility as an important factor in estimating ad value (mean range of 3.42-3.53). Hence, it also has an impact on the formation of positive attitudes to advertising. Hypothesis $\mathrm{H} 7$ was confirmed: the advertising value of catalogs and store flyers has a significant positive impact on customers' attitudes to this type of advertising. The results of the research show that the perception of the ad value is positive (mean range of 3.24 to 3.89), and the respondents think that these ads are useful, valuable, and important. Attitudes to advertising through catalogs and flyers are also positive, as shown by the degree of agreement with the statements in the questionnaire (mean range of 3.61-3.89).

In addition, research results confirm the role of entertainment, informativeness, and credibility as significant predictors of the value of catalog and store flyer advertising. Also, the independent variables of entertainment, credibility, and advertising value have a direct significant positive impact on the attitude to advertising. The result is consistent with previous research in the context of different media (Ducoffe, 1996; Braket \& Carr, 2001; Yang et al., 2017).

The scientific contribution of this research stems from new insights related to the perceptions of and attitudes to advertising through catalogs and store flyers. A systematic review and analysis of the literature defined the theoretical framework of the research that enabled the testing of the advertising value model, in the context of catalogs and flyers, in the Republic of Croatia. In addition to the scientific contribution, the research also has its practical application. Marketing professionals and retailers can use it to learn about and understand the factors that affect the perception of ad value and attitudes to advertising through these media. Such insights contribute to an increase the effectiveness of ads and thus influence future customer behavior in terms of greater media acceptance and, consequently, larger and more frequent purchases. Providing the value that is perceived positively by customers and expected to contribute to their satisfaction leads directly to the desired behavior, i.e., purchase. The results of this research make it possible for marketing professionals to define customer expectations regarding the values they demand from this type of advertising and take action in order to meet such expectation.

The sample used in this survey is a limiting factor in the research. The sample can be considered as a convenience sample given the fact that the links to the survey were delivered to the e-mail addresses available to the author and that the links were posted to Facebook groups and online forums allowing it. From this aspect, its representativeness is questionable.

Future research on this topic should also explore the impact of demographic variables on the perceptions of and attitudes to advertising. The impact of the income per household and the 
place of residence is highlighted as the two variables that are primarily considered in geo-marketing. The correlation between household income and advertising attitudes can provide a clearer picture of customer structure, attitudes, and expectations. A particular feature of these advertising media is that they can target specific geographical areas, which is especially interesting for smaller vendors and family shops. Conse- quently, the influence of the place of residence on attitudes can also be interesting and useful information. The determination of the relationship between catalog design and store flyers is also emphasized, as they are still an interesting medium in their printed form.

In conclusion, we can say that advertising through catalogs and store flyers is interesting and useful for both advertisers and customers.

\section{References}

1. Aaker, D. A., \& Stayman, D. M. (1990). Measuring audience perceptions of commercials and relating them to ad impact. Journal of Advertising Research, 30(4), 7-17.

2. Ahmad, S., Zulkurnain, N. N. A., \& Khairushalimi, F. I. (2016). Assessing the Validity and Reliability of a Measurement Model in Structural Equation Modeling (SEM). British Journal of Mathematics \& Computer Science, 15(3), 1-8.

3. Arora, T., \& Agarwal, B. (2019). Empirical Study on Perceived Value and Attitude of Millennials Towards Social Media Advertising: A Structural Equation Modelling Approach. Journal of Business Perspective, 23(1), 56-69.

4. Awan, A. G., Ismail, M., Majeed, F. C., \& Gmazal, F. (2016). Effects of Advertisement on Consumer's Buying Behaviour with References to FMCG sin Southern Punjab-Pakistan. Journal of Marketing and Consumer Research, 19, 22-30.

5. Aydogan, S., Aysuna, C., \& Aktan, M. (2016). Web Advertising Value and Student's Attitude Towards Web Advertising. European Journal of Business and Management, 8(9), 86-96.

6. Azeem, A., \& Haq, Z. (2012). Perception towards Internet advertising: a study with reference to three different demographic groups. Global Business and Management Research: An International Journal, 4(1), 28-45.

7. Bagozzi, R. P. (1975). Marketing as Exchange. Journal of Marketing, 39, 32-39.

8. Bennett, G., Ferraira, M., Tsuji, Y., \& Cionfrone, B. (2006). Analysing the effects of advertising type and antecedents on attitude towards advertising in sport. International Journal of Sports Marketing and Sponsorship, 8(1), 56-67.

9. Boateng, H., \& Okoe, A. F. (2015). consumer's attitude towards social media advertising and their behavioural response: The moderating role of corporate reputation. Journal of Research in Interactive Marketing, 9(4), 299-312.

10. Bracket, K. L., \& Carr, N. B. (2001). Cyberspace Advertising vs. Other Media: Consumer vs. Mature Student Attitudes. Journal of Advertising Research, 41(5), 23-32.

11. Burton, S., Lichtenstein, D., \& Netemeyer, R. (1999). Exposure to Sales Flyers and Increased Purchases in Retail Supermarkets. Journal of Advertising Research, 39(5), 7-14.

12. Dalrymple, D. J., \& Parsons, L. J. (1995). Marketing management: Text and Cases. New Jersey, NJ: John Wiley \& Sons.

13. Dar, A. N., Ahmed, A. M., Muzaffar, H. M., Nawaz, K., \& Zahid, Z. (2014). Facebook versus Television: Advertising value perception among Students. International Journal of Business and Management Invention, 3(9), 61-70.

14. Ducoffe, H. R., \& Curlo, E. (2000). Advertising value and advertising processing, Journal of Marketing Communication, 6, 247-262 
15. Ducoffe, R. H. (1995). How Consumers Assess the Value of Advertising. Journal of Current Issues \& Research in Advertising, 17(1), 1-18.

16. Ducoffe, R. H. (1996). Advertising value and advertising on the web. Journal of Advertising Research, 36(5), 21-35.

17. Gaber, H. R., Wright, T. L., \& Kooli, K. (2019). Consumer attitudes towards Instagram advertisements in Egypt: The role of the perceived advertising value and personalization. Journal Cogent Business \& Management, 6(1), 1-13.

18. Garcia-Boto, D., \& Alvarez, A. (2020). Modeling the effect of store flyers on supermarket sales: An application to olive oil demand. Journal of Retailing and Consumer Services, 54.

19. Gázquez-Abad, J. C., \& Sánchez-Pérez, M. (2009). How Store Flyers Affect Consumer Choice Behaviour: National Brands vs. Store Brands. European Retail Research, 23(1), 1-20.

20. Gázquez-Abad, J. C., Martínez-López, F. J., \& Barrales-Molina, V. (2014). Profiling the flyer-prone consumer. Journal of Retailing and Consumer Services, 21(6), 966-975.

21. Geller, K. L. (2002). Response - The Complete Guide to Profitable Direct marketing. Oxford: Oxford University Press.

22. Grewal, D., Monroe, K., \& Krishnan, R. (1998). The effect of price comparison advertising on buyers' perception of acquisition value and transaction value. Journal of Marketing, 62, 46-59.

23. Groucutt, J., Leadley, P., \& Forsyth, P., (2004). Marketing, essential principles, new realities. London: Kogan Page.

24. Hair Jr., F. J., Black, R. E., Babin, J. B., \& Anderson, E. R. (2014). Multivariate Dana Analysis. Harlow: Pearson.

25. Haller, T. F. (1974). What students think of advertising. Journal of Advertising Research, 14, 33-38.

26. Halmi, A. (2016). Multivarijantna analiza. Zagreb: Alineja.

27. Hamouda M. (2018). Understanding social media advertising effect on consumers' responses: An empirical investigation of tourism advertising on Facebook. Journal of Enterprise Information Management, 37(3), 426-445.

28. Haq, Z. (2009). Email advertising: A study of consumer attitude toward email advertising among Indian users. Journal of Retail \& Lesure property, 8, 207-223.

29. Houston, F. S., \& Gassenheimer, J. B. (1987). Marketing and exchange. Journal of Marketing, 51, 3-18.

30. Hu, L., \& Bentler, P. M. (1999). Cutoff criteria for fit indexes in covariance structure analysis: Conventional criteria versus new alternatives. Structural Equation Modeling, 6(1), 1-55.

31. Huq, S. M., Alam S. M. S., Nekmahmud, M., Aktar, M. S., \& Alam, S. M. S. (2015). Customer's Attitude Towards Mobile Advertising in Bangladesh. International Journal of Economics and Business Research, 4(6), 281-292.

32. Inanç, S. A., Gökaliler, E., \& Gülay, A. (2020). Do bumper ads bump consumers? An empirical research on YouTube video viewers. El profesional de la informacion, 29(1), 1-13.

33. Kato, R., \& Hoshino, T. (2019). The Impact of Competitors' Store Flyer Advertisements on EDLP/ High-Low Chain Performance in a Highly Competitive Retail Market: GPS Information and POS Data Approach in Japan. Journal of Advertising, 48(5), 1-19.

34. Kelly, L., Kerr, G., \& Drennan, J. (2010). Avoidance of Advertising in Social Networking Sites. Journal of Interactive Advertising, 10(2), 16-27.

35. Kim, J. Y., \& Han, Y. I. (2014). Why smartphone advertising attracts customers: A model of web advertising, flow, and personalization. Computer sin Human Behavior, 38, 256-269.

36. Kim, Y. J., \& Lee, W-N. (2009). Overcoming Consumer Skepticism in Cause-Related Marketing: The Effects of Corporate Social Responsibility and Donation Size Claim Objectivity. Journal of Promotion Management, 15(4), 465-483.

37. Knopper, D. (1993). How About Adding Value to the Advertising Message. Advertising Age, 12(18). 
38. Kotler, P., \& Armstrong, G. (2018). Principles of marketing. London: Pearson.

39. Kotler, P., Kartajaya, H., \& Setiawan, I. (2017). Marketing 4.0 - Moving from Traditional to Digital. New Jersey, NJ: John Wiley \& Sons.

40. Latusi, B. L., Vergura, T. D., \& Lugli, G. (2014). The impact of store flyers on store performance: a format and customer related approach. International Journal of Retail \& Distribution Management, 42(3), 219-234.

41. Lin, T. T. C., \& Bautista, J. R. (2018). Content-related factors influence perceived value of location-based mobile advertising. Journal of Computer Information Systems, 60(2), 184-193.

42. Liu, C. L. E., Sinkovics, R. R., Pezderka, N., \& Haghirian, P. (2012). Determinants of consumer perceptions toward mobile advertising - A comparison between Japan and Australia. Journal of Interactive Marketing, 26(1), 21-32.

43. Loureiro, S. M. C. (2017). Tell What You Want but Do Not irritate Me: A Senior Perspective About Advertising. Journal of Promotion Management, 24(2), 198-214.

44. Mehta, A. (2000). Advertising attitudes and advertising effectiveness. Journal of Advertising Research, 40(3), 67-72.

45. Milaković, K. M., \& Mihić, M. (2015). Predictors and Outcome of Attitudes Toward advertising: Demographic, Personal Factors and WOM. Ekonomska misao i praksa, 24, 409-432.

46. Miller, N. R. (1995). Multinational Direct Marketing. New York, NY: McGraw-Hill.

47. Miranda, M. J., \& Konya, L. (2007). Directing store flyers to the appropriate audience. Journal of Retailing and Consumer Services, 14(3), 175-181.

48. Mulhern, F. J., \& Leone, R. P. (1990). Retail promotional advertising: Do the number of deal items and size of deal discounts affect store performance?. Journal of Business Research, 21, 179-194.

49. Murillo, E., Merino, M., \& Núñez, A. (2016). The advertising value of Twitter Ads: a study among Mexican Millennials. Revista Brasileira de Gestao de Negocios, 18(61), 436-456.

50. Noprisson, H., Husin, N., Zulkarnaim, N., Rahayu, P., Ramadhan, A., \& Sensuse, D. I. (2016). Antecedent factors of consumer attitudes toward SMS, Email and social media for advertising. 2016 International Conference on Advanced Computer Science and Information Systems (ICACSIS).

51. Park, E., \& Kim, K. J. (2014). An Integrated Adoption Model of Mobile Cloud Services: Exploration of Key Determinants and Extension of Technology Acceptance Model. Telematics and Informatics, 37(3), 376-385.

52. Peppers, D., \& Rogers, M. (2017). Managing Customer Experience and Relationships. New Jersey, NJ: John Wiley \& Sons.

53. Pollay, R. W., \& Mittal, B. (1993). Here's the Beef: Factors, Determinants, and Segment sin Consumer Criticism of Advertising. Journal of Marketing, 57(3), 99-114.

54. Qin, L., \& Yan, H. (2017). Attitude towards Mobile Advertising and Mobile Web Information Acquisition Behavior: Perspectives from the Advertising Value, Credibility and Self-efficacy, Advances in Social Science. Education and Humanities Research, 72, 368-373.

55. Rejesh, S., Raj, G., Dhuvandranand, E., \& Kiran, D. (2019). Factors Influencing Customers' Attitude Toward SMS Advertisement: Evidence from Mauritius. Studies in Business and Economics, 14(2), 141-159.

56. Simon, F. (2016). Consumer adoption of No Junk Mail stickers: An extended planned behavior model assessing the respective role of store flyer attachment and perceived intrusiveness. Journal of Retailing and Consumer Services, 29, $12-21$.

57. Spack, P. S., \& Elliot, M. T. (1997). Predictors of Advertising in Print and Broadcast Media. Journal of Advertising, 26(3), 61-76.

58. Srinivasan, V. S., \& Bodapati, A. V. (2006). The Impact of Feature Advertising on Customer Store Choice. Working paper. Standard Graduate School of Business. 
59. Stewart, D. W., \& Pavlou, P. A. (2002). From Consumer Response to Active Consumer: Measuring the Effectiveness of Interactive Media. Journal of the Academy of Marketing Science, 30(4), 376-396.

60. Subroto, S. A., \& Samidi, S. (2018). The influence of advertisement towards brand choice: An exploration from initial attitude of consumers. Management Science Letters, 8, 963-974.

61. Swoboda, B., Elsner, S., Foscht, T., \& Schramm-Klein, H. (2010). Doing the Right Things and doing the things Right - endorses in retail store flyer advertising. Advances in Consumer research, 37, 554-595.

62. Tahereh, N., \& Zahra, G. T. (2012). Investigating Effective Factors on the Perceived Values and Attitudes of Internet Advertisements Users. Journal of Basic and Applied Scientific Research, 2(5), 4392-4399.

63. Tsang, M. M., Ho, S. C., \& Liang, T. P. (2004). Consumer attitudes toward mobile advertising: An empirical study. International Journal of Electronic Commerce, 8(3), 65-78.

64. Tüzünkan D., \& Altintas, V. (2019). Contemporary Human Resources Management in Tourism Industry. New York, NY: IGI Global.

65. Wang, S-L., \& Lan, N. T. N. (2018). A Study on the Attitude of Customer towards Viral Video Advertising on Social Media: A Case Study in Viet Nam. International Journal of Engineering and Science, 7(6), 54-60.

66. Wang, Y., Genc, E., \& Peng, G. (2019). Aiming the Mobile Targets in a Cross-Cultural Context: Effect of Trust, Privacy Concerns and Attitude. International Journal of Human-Computer Interaction, 36(3), 227-238.

67. Wood, W. (2000). Attitude Change: Persuasion and Social Influence. Annual Review of Psychology, 51(1), 539-570.

68. Yang, B., Kim, Y., \& Yoo, C. (2013). The integrated mobile advertising model: The effects of technology- and emotion-based evaluations. Journal of Business Research, 66(9), 1345-1352.

69. Yang, K. C., Huang, C. H., Yang, C., \& Yang, S. Y. (2017). Consumer attitudes toward online video advertisement: YouTube as a platform. Kybernets, 46(5), 840-853.

70. Zhang, P., \& Wang, C. (2005). An empirical study on consumer's perceived value and attitude toward advertising. Proceedings of the $6^{\text {th }}$ Global Information Technology and Management World Conference, June 5-7, 2005, Anchorage, Alaska. 